\title{
Analisis Pengaruh Variabel Makroekonomi Terhadap Profitabilitas Pada Perusahaan Pertambangan
}

\author{
Seno Hadi Saputro \\ STMIK Atma Luhur \\ e-mail : seno.hadi@atmaluhur.ac.id
}

\begin{abstract}
(Saputro, 2019)Saputro, S. H. (2019). Analisis Pengaruh Variabel Makroekonomi Terhadap Profitabilitas Pada
\end{abstract} Perusahaan Pertambangan. Moneter, 6(1), 91-96.

\begin{abstract}
The company's survival is influenced by many things, among others is profitability of the company. The company's profitability is determined by various factors, one of which is an external factor. External factor are beyond the company's difficult part is controlled by the company. Macroeconomic factor are the external factors of the company. This study was conducted to evaluate the effect of GDB, BI Rate, Inflation and the exchange rate on the profitability of mining companies. The population using a mining company in Indonesia stock exchange in 2014-2018. Methodology research as the sample used purposive sampling technique sampling with particular determination in order to obtain a representative sample according to the sample criteria that will be used. Detrmination of sampling techniques was obtained 34 mining companies. Data were analyzed using multiple regression method data panel random effect. The result obtained showed the BI Rate has a negative effect on the profitability of mining companies, namely when the BI Rate is low, the company's ability to fund its investment will increase. Whereas GDB, Inflation and exchange rate does not affect the profitability of mining companies.
\end{abstract}

Keywords: GDB, BI rate, Inflation, Kurs, Profitability

\section{PENDAHULUAN}

Di Indonesia semakin banyak jumlah perusahaan yang berkembang saat ini, baik yang bergerak dalam bidang industri, perdagangan dan jasa. Setiap perusahaan baik yang skala kecil maupun besar mempunyai tujuan yang telah ditetapkan sebelumnya. Kondisi perusahaan yang baik merupakan kekuatan untuk perusahaan bertahan dan berkembang demi tercapainya tujuan perusahaan. Namun dalam era globalisasi seperti sekarang ini, mengakibatkan persaingan antara perusahaan semakin ketat (Rahmah, Cipta, \& Yudiaatmaja, 2016).

Perusahaan atau organisasi melakukan berbagai aktivitas untuk mencapai tujuan yang telah ditetapkan sebelumnya. Upaya untuk mencapai tujuan itu, perusahaan harus dapat beroperasi secara lancar dan dapat mengkombinasikan semua sumber daya yang ada, sehingga dapat mencapai hasil dan tingkat laba yang optimal. Kelangsungan hidup perusahaan dipengaruhi oleh banyak hal antara lain profitabilitas perusahaan itu sendiri. Profitabilitas merupakan salah satu faktor untuk menilai baik buruknya kinerja perusahaan. Return On Asset (ROA) merupakan rasio profitabilitas yang digunakan untuk mengukur efektivitas perusahaan di dalam menghasilkan keuntungan dengan memanfaatkan total aktiva yang dimilikinya. (Barus \& Ratio, 2013)

Keberlangsungan sebuah perusahaan ditentukan oleh berbagai macam faktor, salah satunya adalah faktor eksternal. Faktor eksternal merupakan bagian dari luar perusahaan yang sulit dikendalikan oleh perusahaan bahkan krisis ekonomi secara makro dapat menyebabkan banyak perusahaan mengalami kebangkrutan sehingga perusahaan harus peka terhadap kondisi makroekonomi (Sulaksana, 2016).

Dipilihnya perusahaan pertambangan sebagai sampel penelitian karena ROA perusahaan tersebut mengalami kenaikan maupun penurunan yang signifikan. Sebagai contoh PT. Adaro Energy, Tbk. Pada tahun 2017 memiliki ROA sebesar 0,0787 sedangkan pada tahun 2018 memiliki ROA sebesar 0,0330. Apabila dibandingkan ROA tahun 2017 dan 2018 maka ROA perusahaan tersebut mengalami penurunan sebesar -0,5807. Sedangkan untuk tahun 2016 dan 2017 ROA perusahaan mengalami kenaikan sebesar 0,5077. Dari data tersebut diduga dipengaruhi kondisi makroekonomi. Dalam penelitian ini faktor makroekonomi yang digunkan adalah PDB, BI Rate, Inflasis dan Kurs. Perbedaan penelitian ini dengan penelitian terdahulu, beberapa penelitian terdahulu yang membahas tentang profitabilitas mempunyai fokus bidang yang berbeda. (Hidayati, 2014) meneliti tentang profitabilitas Bank Syariah di Indonesia, sedangkan (Krissandy, 2013) meneliti tentang profitabilitas Bank Muammalat Di Indonesia. Adapun penelitian ini lebih memfokuskan pada perusahaan pertambangan.

\section{METODOLOGI PENELITIAN}

1 Pengembangan Hipotesis

a. PDB

Menurut Mankiw (2012) dalam (Krissandy, 2013), PDB adalah nilai pasar dari sejumlah barang dan jasa akhir yang diproduksi dalam sebuah negara pada suatu periode. PDB dapat mengukur total pendapatan maupun total 
pengeluaran perekonomian untuk barang dan jasa. Sehingga PDB per orang dapat memberitahu kita pendapatan dan pengeluaran dari rata-rata seseorang dalam perekonomian, karena kebanyakan orang lebih memilih pendapatan dan pengeluaran yang lebih tinggi. PDB dibagi dalam empat komponen pengeluaran : konsumsi, investasi, pembelanjaan pemerintah, dan eksport netto. Konsumsi termasuk pembelanjaan barang dan jasa oleh rumah tangga, investasi meliputi pembelanjaan perlengkapan dan bangunan, termasuk pembelian tempat tinggal baru oleh rumah tangga. Pembelanjaan pemerintah termasuk dalam pembelanjaan barang dan jasa oleh pemerintah daerah, negara bagian dan pusat. Eksport netto sama dengan nilai barang dan jasas yang diproduksi didalam negeri dan dijual diluar negeri (eksport) dikurangi nilai barang dan jasa yang diproduksi diluar negeri (import). PDB yang meningkat mempunyai pengaruh yang positif terhadap daya beli konsumen sehingga dapat meningkatkan permintaan terhadap produk perusahaan yang pada akhirnya dapat meningkatkan profitabilitas perusahaan. Hal tersebut senada dengan hasil penelitian (Sahara, 2013) dan (Sodiq, 2015) yang menyebutkan bahwa PDB berpengaruh positif terhadap ROA. Berdasarkan penjelasan ini maka hipotesis pada penelitian ini adalah:

H1 : PDB berpengaruh positif terhadap profitabilitas

b. BI Rate dan Profitabilitas

Dalam (Saputro, 2018), BI Rate adalah suku bunga kebijakan yang mencerminkan sikap atau stance kebijakan moneter yang ditetapkan oleh Bank Indonesia dan diumumkan kepada publik. BI Rate diumumkan oleh gubernur Bank Indonesia setiap rapat dewan gubernur bulanan dan diimplementasikan pada operasi moneter yang dilakukan oleh Bank Indonesia melalui pengelolaan likuiditas (Liquidity Management) di pasar uang untuk mencapai sasaran operasional kebijakan moneter. Hampir setiap perusahaan membutuhkan pembiayaan baik itu dari pemegang saham ataupun pihak eksternal seperti Bank. Bisnis membutuhkan pembiayaan untuk mendanai berbagai aktivitas bisnisnya agar terus bisa menghasilkan kesejahteraan bagi pemegang saham. Ketika BI Rate naik, maka akan diikuti oleh naiknya suku bunga lain dalam konteks ini suku bunga kredit. Naiknya suku bunga kredit akan meningkatkan biaya sehingga kondisi ini akan menurunkan kemampuan perusahaan untuk mengembangkan bisnisnya. Hal tersebut senada dengan penelitian (Kurniawati, Hamzah, \& Kunawangsih, 2018) dan (Aldiansyah, 2018) yang menyebutkan bahwa BI Rate berpengaruh negatif terhadap ROA. Berdasarkan penjelasan ini maka hipotesis pada penelitian ini adalah:
H2 : BI Rate berpengaruh negatif terhadap profitabilitas

c. Inflasi dan Profitabilitas

Menurut Sukirno dalam (Saputro, 2018), inflasi adalah kenaikan harga-harga secara umum berlaku dalam suatu perekonomian dari suatu periode ke periode lainnya, sedangkan tingkat inflasi adalah presentasi kenaikan harga-harga pada suatu tahun tertentu disbanding dengan tahun sebelumnya. Berdasarkan kepada tingkat kelajuan kenaikan harga-harga yang berlaku, inflasi dapat dibedakan menjadi 3 golongan yaitu :

1) Inflasi merayap adalah proses kenaikan hargaharga yang lambat jalannya. Yang digolongkan pada inflasi ini adalah kenaikan harga-harga yang tingkatnya tidak melebihi dua atau tiga persen setahun.

2) Hyperinflasi adalah proses kenaikan hargaharga yang sangat cepat, yang menyebabkan tingkat harga menjadi dua atau beberapa kali lipat dalam masa yang singkat.

3) Inflasi sederhana adalah tingkat inflasi di Negara berkembang yang ada kalanya tidak mudah dikendalikan. Negara-negara tersebut tidak mengalami masalah hyperinflasi, akan tetapi juga tidak mampu menurunkan inflasi pada tingkat yang sangat rendah. Secara ratarata di sebagian Negara tingkat inflasi mencapai 5 sampai dengan $10 \%$.

Kenaikan harga barang yang disebabkan inflasi tentunya akan menambah pengeluaran produksi perusahaan pertambangan. Apabila pengeluaran produksi bertambah, maka akan mengurangi laba perusahaan tersebut. Hal tersebut senada dengan penelitian (Kalengkongan, 2011) dan (Putra, 2014) yang menyebutkan bahwa inflasi berpengaruh negatif terhadap profitabilitas. Berdasarkan penjelasan ini, maka hipotesis pada penelitian ini adalah :

H3 : Inflasi berpengaruh negatif terhadap profitabilitas

d. Kurs dan Profitabilitas

Menurut Sukirno dalam (Hidayati, 2014), kurs mata uang asing menunjukkan harga atau nilai mata uang sesuatu negara dinyatakan dalam mata uang negara lain. Kurs mata uang asing dapat juga didefinisikan sebagai jumlah uang domestik yang dibutuhkan, yaitu banyaknya rupiah yang dibutuhkan untuk memperoleh satu unit mata uang asing. Nilai tukar yang digunakan dalam penelitian ini adalah niai tukar rupiah terhadap dollar amerika serikat. Nilai tukar satu mata uang tersebut terapresiasi atau terdepresiasi. Ketika mata uang suatu negara melemah terhadap mata uang negara lain, biaya produksi yang mengandalkan bahan baku impor akan naik. Kondisi ini secara otomatis akan menurunkan laba perusahaan atau margin laba. Hal tersebut senada dengan penelitian (Hidayati, 2014) dan (Prastowo, Malavia, \& Wahono, 2014) yang 
menyebutkan bahwa Kurs berpengaruh positif terhadap profitabilitas. Berdasarkan penjelasan ini, maka hipotesis penelitian ini adalah :

H4 : Kurs berpengaruh positif terhadap profitabilitas

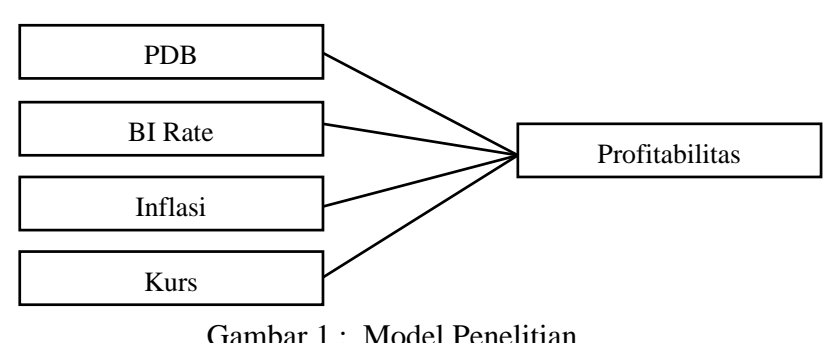

\section{Metode Pengambilan Sampel}

Penelitian ini merupakan jenis penelitian eksplanatori dengan pendekatan kuantitatif. Menurut (Sugiyono, 2012), penelitian eksplanatori merupakan penelitian yang bermaksud menjelaskan kedudukan variabelvariabel yang diteliti serta hubungan antara satu variabel dengan yang lain.

Dalam penelitian ini pengambilan sampel dilakukan berdasarkan metode pengambilan sampel bertujuan (purposive sampling) yaitu teknik penentuan sampling dengan pertimbangan tertentu / Judgment Sampling dengan tujuan untuk mendapatkan sampel yang representatif sesuai dengan kriteria sampel sebagai berikut :

a. Periode pengamatan dilakukan 5 tahun berturutturut yaitu tahun 2014, 2015, 2016, 2017 sampai dengan Juni 2018.

b. Perusahaan pertambangan yang dijadikan sampel penelitian adalah perusahaan pertambangan yang menyampaikan laporan keuangan sampai dengan bulan Juni 2018.

Dari kriteria sampel yang diberikan diatas, didapatkan data dalam tabel 1 sebagai berikut : Tabel 1

Daftar Perusahaan Pertambangan Yang Dijadikan Sampel Penelitian

\begin{tabular}{lll}
\hline No. & Kode & Nama Perusahaan \\
\hline 1. & ADRO & Adaro Energy, Tbk \\
\hline 2. & ARII & Atlas Resources, Tbk \\
\hline 3. & ATPK & Bara Jaya Internasional, Tbk \\
\hline 4. & BSSR & Baramulti Suksessarana, Tbk \\
\hline 5. & BUMI & Bumi Resources, Tbk \\
\hline 6. & BYAN & Bayan Resources, Tbk \\
\hline 7. & DEWA & Darma Henwa, Tbk \\
\hline 8. & DOID & Delta Dunia Makmur, Tbk \\
\hline 9. & GEMS & Golden Energy Mines, Tbk \\
\hline 10. & GTBO & Garda Tujuh Buana, Tbk \\
\hline 11. & HRUM & Harum Energy, Tbk \\
\hline 12. & ITMG & Tambangraya Megah, Tbk \\
\hline 13. & KKGI & Resources Alam Indonesia, Tbk \\
\hline 14. & MBAP & Mitrabara Adiperdana, Tbk \\
\hline 15. & PTBA & Bukit Asam, Tbk \\
\hline 16. & MYOH & Samindo Resources, Tbk \\
\hline 17. & PKPK & Perdana Karya Perkasa, Tbk \\
\hline 18. & ARTI & Ratu Prabu Energi, Tbk \\
\hline
\end{tabular}

\begin{tabular}{lll}
\hline 19. & BIPI & Benakat integra, Tbk \\
\hline 20. & ELSA & Elnusa, Tbk \\
\hline 21. & ENRG & Energi Mega Persada, Tbk \\
\hline 22. & ESSA & Surya Esa Perkasa, Tbk \\
\hline 23. & MEDC & $\begin{array}{l}\text { Medco Energi Internasional, } \\
\text { Tbk }\end{array}$ \\
\hline 24. & RUIS & Radiant Utama Interinsco, Tbk \\
\hline 25. & ANTM & Aneka Tambang, Tbk \\
\hline 26. & CITA & Cita Mineral Investindo, Tbk \\
\hline 27. & CKRA & Cakra Mineral, Tbk \\
\hline 28. & DKFT & Central Omega Resources, Tbk \\
\hline 29. & INCO & Vale Indonesia, Tbk \\
\hline 30. & PSAB & J Resources Asia Pasifik, Tbk \\
\hline 31. & SMRU & SMR Utama, Tbk \\
\hline 32. & TINS & Timah, Tbk \\
\hline 33. & CTTH & Citatah, Tbk \\
\hline 34. & MITI & Mitra Investindo, Tbk \\
\hline
\end{tabular}

Metode penelitian yang digunakan untuk menganalisis pengaruh Growth, PDB, BI Rate, Inflasi dan nilai tukar terhadap ROA perusahaan pertambangan adalah analisis data panel. Perangkat lunak yang digunakan dalam penelitian ini adalah Microsoft Excel 2007 untuk mengelompokkan data dan selanjutnya diolah menggunakan software Eviews 6.

\section{Metode Analisis Data}

Metode analisis yang digunakan dalam penelitian ini adalah analisis regresi berganda dengan panel data. Menurut Agus Widarjono (2013) dalam (Saputro, 2014), Panel data atau disebut data longitudinal adalah sekelompok data individual yang diteliti selama rentang waktu tertentu. Panel data merupakan gabungan dari time series data dan cross section data. Model panel data terdiri dari 3 bentuk yaitu :

a. Ordinary Least Square

Metode Ordinary Least Square dikenal dengan estimasi Common effect. Dalam pendekatan ini tidak memperhatikan dimensi individu maupun waktu. Diasumsikan bahwa perilaku data antar perusahaan sama dalam berbagai kurun waktu.

b. Fixed Effect

Pengertian Fixed effect ini didasarkan adanya perbedaan intersep antara perusahaan namun intersep nya sama antar waktu (time invariant). Disamping itu, model fixed effect juga mengasumsikan bahwa koefisien regresi (slope) tetap antar perusahaan dan antar waktu

c. Random Effect

Didalam model ini kita akan mengestimasi data panel dimana variabel gangguan mungkin saling berhubungan antar waktu dan antar individu

4. Pengujian Pemilihan Model dalam Pengolahan Data Panel

a. Uji Chow (Chow Test)

Uji chow dilakukan untuk memilih model yang digunakan Common Effect atau Fixed Effect. Pengujian ini dilakukan dengan hipotesa sebagai berikut :

$\mathrm{H}_{0}$ : Model Common Effect 
$\mathrm{H}_{1}$ : Model Fixed Effect

Dasar penolakan terhadap hipotesa nol tersebut adalah dengan menggunakan Rumus :

$$
\text { Chow }=\frac{(E S S 1-E S S 2) /(N-1)}{E S S 2 /(N T-N-K)}
$$

Dimana :

ESS1 = Residual Sum Square hasil pendugaan model Common Effect

ESS2 = Residual Sum Square hasil pendugaan model Fixed Effect

$\mathrm{N}=$ Jumlah data cross section

$\mathrm{T}=$ Jumlah data time series

$\mathrm{K}=$ Jumlah variabel penjelas

Jika nilai Chow statistics hasil pengujian lebih besar dari $\mathrm{F}$ tabel, maka Ho ditolak, begitu juga sebaliknya.

b. Uji Hausman (Hausman Test)

Uji hausman dilakukan untuk memilih model yang digunakan Fixed Effect atau Random Effect. Pengujian ini dilakukan dengan hipotesa sebagai berikut :

\section{$\mathrm{H}_{0}$ : Model Random Effect}

$\mathrm{H}_{1}$ : Model Fixed Effect

Jika nilai hausman hasil pengujian lebih besar dari $\mathrm{X}^{2}$ tabel, maka Ho ditolak, begitu juga sebaliknya.

c. Uji Lagrange Multiplier (LM Test)

Uji lagrange multiplier dilakukan untuk memilih model yang digunakan Common Effect atau Random Effect. Pengujian ini dilakukan dengan hipotesa sebagai berikut :

\section{$\mathrm{H}_{0}$ : Model Common Effect}

$\mathrm{H}_{1}$ : Model Random Effect

Jika nilai Lagrange Multiplier hasil pengujian lebih besar dari $\mathrm{X}^{2}$ tabel, maka Ho ditolak, begitu juga sebaliknya.

\section{Evaluasi Model}

a. Uji t (Uji Parsial)

Uji parsial ( $t$ test) dilakukan untuk menguji signifikansi pengaruh variabel-variabel independen, yaitu Growth, PDB, BI Rate, Inflasi dan nilai tukar secara individual terhadap variabel dependen, yaitu Return On Asset (ROA) tahun 2012-2018. Tahap-tahap pengujiannya adalah :

1) Merumuskan hipotesis.

$\mathrm{H}_{0}: \mathrm{b} 1 \ldots \mathrm{b} 4=0$, artinya tidak ada pengaruh antara variabel independen terhadap variabel dependen.

$\mathrm{H}_{\mathrm{a}}: \mathrm{b} 1 \ldots . \mathrm{b} 4 \neq 0$, artinya ada pengaruh antara variabel independen terhadap variabel dependen.

2) Menentukan tingkat signifikansi yaitu 0,05 atau $5 \%$.

3) Menentukan keputusan dengan membandingkan $t$ hitung dengan $t$ tabel dengan kriteria sebagai berikut:

ika $t$ hitung $>\mathrm{t}$ tabel atau $-\mathrm{t}$ hitung $<-\mathrm{t}$ tabel, maka Ho ditolak
Jika t hitung < t tabel atau -t hitung $>-\mathrm{t}$ tabel, maka Ho diterima

b. R Squared

$R$-Squared adalah proporsi variasi dalam variabel dependen yang dapat dijelaskan oleh variabelvariabel independennya. $R$-Squared memiliki range $0 \leq R$-Squared $\leq 1$. Jika $R$-Squared bernilai 1 maka 100 persen variasi dalam variabel dependen dapat dijelaskan oleh variabel-variabel independennya. Sedangkan jika R-Squared bernilai 0 maka variasi dalam variabel dependen tidak dapat dijelaskan oleh variabel-variabel independennya.

\section{HASIL DAN PEMBAHASAN}

\section{Hasil}

Pengujian Pemilihan Model Data Panel

a. Uji Chow

Dari uji chow didapatkan hasil 6,439238 sedangkan besarnya $\mathrm{F}$ tabel dengan derajat bebas N-1 (33) dan NT-N-K (132) sebesar 1,3940. Karena $\mathrm{F}$ hitung $>\mathrm{F}$ tabel maka $\mathrm{H}_{0}$ ditolak. Dengan demikian dapat disimpulkan bahwa model Fixed Effect lebih sesuai digunakan didalam penelitian ini daripada Common Effect.

b. Uji Hausman

Dari uji hausman didapatkan hasil -180,0896 sedangkan nilai kritis Chi Squares dengan n-1 sebesar 33 pada $\alpha=5 \%$ sebesar 55,758. karena uji hausman $<\mathrm{X}^{2}$ tabel maka $\mathrm{H}_{0}$ diterima. Dengan demikian dapat disimpulkan bahwa model Random Effect lebih sesuai digunakan didalam penelitian ini daripada Fixed Effect.

Model data panel dengan menggunakan model Random Effects ditampilkan pada tabel 2.

Tabel 2.Metode Random Effects

\begin{tabular}{lclc}
\multicolumn{4}{c}{ Tabel 2.Metode Random Effects } \\
\hline \multicolumn{1}{c}{ Variabel } & Coefficient & \multicolumn{1}{c}{ t-Statistic } & Prob \\
\hline C & 59,42202 & 0,767145 & 0,4446 \\
Log PDB & $-21,36002$ & $-1,931105$ & 0,0560 \\
Log BIRate & $-2,876459$ & $-2,251354$ & 0,0263 \\
Log Inflasi & $-0,275137$ & $-0,336031$ & 0,7375 \\
Log Nilai Tukar & $-14,29534$ & $-1,402672$ & 0,1635 \\
\hline \multicolumn{4}{c}{} \\
\hline R-Squared & 0,540990 & Mean dependent & $-3,511706$ \\
Adjusted R- & 0,524449 & var & \\
Squared & & S.D. dependent & 1,556699 \\
S.E. of & 1,073503 & var & \\
regression & 1,738649 & Sum squared & 127,9174 \\
Durbin-Watson & & resid & \\
Stat & & &
\end{tabular}

Nilai signifikansi uji t pada PDB sebesar 0,0560 ( sig $>0,05$ ) ini berarti PDB tidak signifikan terhadap ROA, koefisien regresi memiliki arah negatif sebesar -21,36002. Apabila dibandingkan antara t hitung dan $\mathrm{t}$ tabel maka didapatkan hasil -t hitung $>-2,03452$ ini berarti PDB tidak berpengaruh terhadap ROA. Dari hasil analisis tersebut PDB tidak berpengaruh terhadap ROA. Dari pengujian yang sudah dilakukan, maka hipotesis 1 (H1) ditolak. Nilai signifikansi uji t 
pada BI Rate sebesar 0,0263 ini berarti BI Rate signifikan terhadap ROA, koefisien regresi memiliki arah negatif sebesar -2,876459. Apabila dibandingkan antara $\mathrm{t}$ hitung dan $\mathrm{t}$ tabel maka didapatkan hasil -t hitung < -2,03452 ini berarti BI Rate berpengaruh terhadap ROA. Dari pengujian yang sudah dilakukan, maka hipotesis 2 (H2) diterima. Nilai signifikansi uji t pada inflasi sebesar 0,7375 ini berarti inflasi tidak signifikan terhadap ROA, koefisien regresi memiliki arah negatif sebesar $-0,275137$. Apabila dibandingkan antara t hitung dan $\mathrm{t}$ tabel maka didapatkan hasil -t hitung > -2,03452 ini berarti inflasi tidak berpengaruh terhadap ROA. Dari pengujian yang sudah dilakukan, maka hipotesis 3 (H3) ditolak. Nilai signifikansi uji t pada kurs sebesar 0,1635 ini berarti nilai tukar tidak signifikan terhadap ROA, koefisien regresi memiliki arah negatif sebesar $-14,29534$. Apabila dibandingkan antara t hitung dan $\mathrm{t}$ tabel maka didapatkan hasil -t hitung > -2,03452 ini berarti kurs tidak berpengaruh terhadap ROA. Dari hasil analisis tersebut kurs tidak berpengaruh terhadap ROA.

\section{R Squared}

Hasil estimasi dengan menggunakan model efek random (Random Effect) menunjukkan nilai $\mathrm{R}^{2}$ atau koefisien determinasi pada hasil estimasi tersebut dapat diketahui bahwa 54,09 persen keragaman ROA perusahaan pertambangan yang menjadi sampel pada periode waktu 2014-2018 dapat dijelaskan oleh variabel bebasnya (PDB, BI Rate, inflasi dan nilai tukar), sedangkan 45,91 persen dijelaskan oleh variabel lain di luar model seperti kinerja perusahaan pertambangan tersebut, kebijakan pemerintah terhadap pembatasan ekspor dan impor perusahaan pertambangan dan sebagainya.

\section{Pengaruh PDB Terhadap Profitabilitas}

Hasil penelitian menunjukkan bahwa PDB tidak berpengaruh terhadap profitabilitas. Meningkatnya PDB mempunyai pengaruh yang positif terhadap daya beli konsumen sehingga dapat meningkatkan permintaan terhadap produk perusahaan yang pada akhirnya dapat meningkatkan profitabilitas perusahaan. Namun berdasarkan penelitian ini hal tersebut tidak terjadi karena ketika pada PDB mengalami peningkatan pada tahun tertentu, profitabilitas mengalami kenaikan. Akan tetapi di tahun yang berbeda, ketika PDB mengalami peningkatan, profitabilitas mengalami penurunan. Pada tahun 2017 dan 2018, Pada perusahaan PT. Adaro Energy, Tbk (ADRO), PDB mengalami peningkatan sebesar 0,019 sedangkan ROA mengalami penurunan sebesaar -0,581. Sedangkan pada tahun 2016 dan 2017, perusahaan tersebut mengalami kenaikan sebesar 0,02 sedangkan ROA mengalami kenaikan sebesar 0,508. Hal ini bertentangan dengan penelitian (Sahara, 2013) dan (Sodiq, 2015) yang menyebutkan bahwa PDB berpengaruh positif terhadap profitabilitas.

\section{Pengaruh BI Rate Terhadap Profitabilitas}

Hasil penelitian menunjukkan bahwa BI Rate berpengaruh negatif terhadap profitabilitas. Tingkat suku bunga acuan (BI Rate) akan berdampak pada kinerja perusahaan pertambangan terutama terhadap kemampuannya untuk memperoleh pembiayaan. Perusahaan memerlukan pembiayaan untuk mendanai operasi dan investasinya. Aktivitas investasi sangat diperlukan untuk menjamin perusahaan dapat menjalankan fungsi dan mencapai tujuannya yaitu profitabilitas perusahaan. Apabila suku bunga meningkat, maka kemampuan perusahaan untuk mendanai investasinya berkurang karena kenaikan BI Rate juga akan diikuti oleh kenaikan suku bunga kredit pada bank umum. Begitu juga sebaliknya, ketika tingkat suku bunga acuan rendah, maka kemampuan perusahaan untuk mendanai investasinya akan meningkat. Hal ini sesuai dengan penelitian (Kurniawati et al., 2018) dan yang menyebutkan bahwa BI Rate berpengaruh negatif terhadap profitabilitas.

\section{Pengaruh Inflasi Terhadap Profitabilitas}

Hasil penelitian menunjukkan bahwa inflasi tidak berpengaruh terhadap profitabilitas. Naiknya harga barang tidak berpengaruh terhadap keuntungan yang dihasilkan. Walaupun perusahaan menaikkan harga produk mereka, tidak akan menurunkan daya beli konsumen terhadap produk perusahaan, sehingga perusahaan masih dapat menghasilkan laba. Karena perusahaan masih dapat bertahan dan masih dapat menghasilkan laba ditengah inflasi yang terjadi, maka mampu menarik investor. Dana yang didapat dari investor tersebut dapat digunakan perusahaan untuk kegiatan operasionalnya sehingga tidak akan mempengaruhi keuntungan yang didapatkan oleh perusahaan pertambangan. Hal ini bertentangan dengan penelitian (Kalengkongan, 2011) dan (Putra, 2014) yang menyebutkan bahwa inflasi berpengaruh negatif terhadap profitabilitas.

\section{Pengaruh Kurs Terhadap Profitabilitas}

Hasil penelitian menunjukkan bahwa kurs tidak berpengaruh terhadap profitabilitas. Nilai tukar mata uang atau kurs rupiah yang menguat terhadap mata uang asing merupakan sinyal positif bagi perekonomian yang mengalami inflasi. Sehingga menguatnya kurs rupiah terhadap mata uang asing dapat menurunkan suku bunga yang berlaku yang pada akhirnya dapat menurunkan profitabilitas perusahaan. Namun berdasarkan penelitian ini hal tersebut nampaknya tidak terjadi pada perusahaan pertambangan karena ketika kurs mengalami peningkatan pada tahun tertentu, profitabilitas mengalami kenaikan. Akan tetapi di tahun yang berbeda, ketika kurs mengalami peningkatan, profitabilitas mengalami penurunan. Hal ini bertentangan dengan penelitian (Hidayati, 2014) dan 
(Prastowo et al., 2014) yang menyebutkan bahwa kurs berpengaruh positif terhadap profitabilitas.

\section{KESIMPULAN}

Penelitian ini bertujuan untuk mengetahui pengaruh variabel makroekonomi terhadap profitabilitas pada perusahaan pertambangan. Perbedaan penelitian ini dengan penelitian sebelumnya adalah dengan menggunakan perusahaan pertambangan sebagai obyek penelitian dan menggunakan model data panel sebagai metode analisis data. Pemilihan model data panel menggunakan model data panel Random Effect setelah dilakukan pengujian dengan menggunakan Chow test dan Hausman test. Hasil uji signifikansi secara individu menunjukkan hasil bahwa BI Rate berpengaruh negatif terhadap profitabilitas perusahaan pertambangan sedangkan PDB, inflasi dan nilai tukar tidak berpengaruh terhadap profitabilitas perusahaan pertambangan.

\section{Keterbatasan Penelitian}

Peneliti menyadari bahwa penelitian terdapat keterbatasan yaitu penelitian ini hanya menggunakan indikator eksternal yang digunakan serta periode tahun penelitian hanya 5 tahun yaitu tahun 20142018. Perusahaan yang dijadikan sampel didalam penelitian ini hanya perusahaan pertambangan

\section{REFERENSI}

Aldiansyah, T. (2018). Pengaruh Inflasi, BI Rate, NPF Dan BOPO Terhadap Profitabilitas Bank Umum Syariah Di Indonesia. 6(1), 133-153.

Barus, A. C., \& Ratio, D. (2013). Analisis FaktorFaktor Yang Mempengaruhi Profitabilitas Pada Perusahaan Manufaktur yang Terdaftar Di Bursa Efek Indonesia. Jurnal Wira Ekonomi Mikroskil, 3, 111-121.

Hidayati, A. N. (2014). Pengaruh Inflasi, BI Rate Dan Kurs Terhadap Profitabilitas Bank Syariah Di indonesia. An-Nisbah, 01(01), 73-97.

Kalengkongan, G. (2011). Tingkat Suku Bunga Dan Inflasi Pengaruhnya Terhadap Return On Asset (ROA) Pada Industri Perbankan Yang Go Public Di Bursa Efek Indonesia. Jurnal Emba, 1(4), 737-747.

Krissandy. (2013). Pengaruh Faktor Internal dan Eksternal Bank Terhadap Profitabilitas pada PT. Bank Muamalat Indonesia, Tbk. Semnas Fekon, 513-521.

Kurniawati, S., Hamzah, Z., \& Kunawangsih, T. (2018). Analisis Pengaruh CAR , LDR , DER, BI Rate dan Inflasi Terhadap ROA Pada 10 Bank Besar Yang Ada di Bursa Efek Indonesia.
(1999), 1183-1190.

Prastowo, P. R., Malavia, R., \& Wahono, B. (2014). Analisis Pengaruh Inflasi, Suku Bunga Dan Nilai Tukar Terhadap Profitabilitas Perbaankan. E-Jurnal Riset Manajemen, 2741.

Putra, R. E. (2014). Pengaruh Risiko Kredit, Inflasi dan BI Rate Terhadap Profitabilitas Bank Pemerintah Yang Ada Di Bursa Efek Indonesia. (1), 14059104.

Rahmah, A. M., Cipta, W., \& Yudiaatmaja, F. (2016). Pengaruh Likuiditas, Solvabilitas Dan Aktivitas Terhadap Profitabilitas Pada Perusahaan Otomotif Yang Terdaftar Di Bursa Efek Indonesia Periode 2012-2014. E-Journal Bisma Universitas Pendidikan Ganesha, 4(1).

Sahara, A. (2013). Analisis Pengaruh Inflasi, Suku Bunga BI, dan Produk Domestik Bruto terhadap Return On Asset (ROA) Bank Syariah di Indonesia. Jurnal Ilmu Manajemen, 1(1), 149-157.

Saputro, S. H. (2014). Pengaruh Growth, Size, Kinerja Perusahaan Dan Indikator Ekonomi Makro Terhadap Return Saham Pada Perusahaan Manufaktur. 25(3), 179-185.

Saputro, S. H. (2018). Analisis Pengaruh Growth, Size, Eva Dan Variabel Makroekonomi Terhadap Perubahan Laba Perusahaan Manufaktur. Jurnal Moneter STMIK Atma Luhur, V(1).

Saputro, S. H. (2019). Analisis Pengaruh Variabel Makroekonomi Terhadap Profitabilitas Pada Perusahaan Pertambangan. Moneter, 6(1), 9196.

Sodiq, A. (2015). Pengaruh variabel makro ekonomi terhadap profitabilitas bank syariah di indonesia periode 2009 - 2014. Jurnal Bisnis Dan Manajemen Islam, 3(2), 344-363.

Sugiyono. (2012). Metode Penelitian Kuantitatif Kualitatif dan $R \& D$. Bandung.

Sulaksana, T. (2016). Analisis Rasio keuangan Dan Variabel Ekonomi Makro Dalam Memprediksi Financial Distress Perusahaan Pertambangan Di Bursa Efek Indonesia Periode 2011-2015. Artikel Ilmiah STIE Perbanas, 2016.

\section{PROFIL PENULIS}

Seno Hadi Saputro, MM adalah dosen tetap di Program Studi Sistem Informasi STMIK Atma Luhur,Pangkalpinang. Mendapatkan gelar Sarjana Ekonomi dari Jurusan Manajemen Fakultas Ekonomi Universitas Muhammadiyah Surakarta. Gelar MM diperoleh dari Jurusan Manajemen Program Pascasarjana Universitas Budi Luhur, Jakarta. 